\title{
Correlation between Environmental and Individual Factors with Dermatitis Contact on Tobacco Farmers
}

\author{
Hubungan antara Faktor Lingkungan dan Individu dengan Dermatitis Kontak \\ pada Petani Tembakau
}

\author{
Ike Puspitasari Singgih Putri, Tri Martiana, Firman Suryadi Rahman \\ Department of Occupational Safety and Health, Faculty of Public Health, Universitas Airlangga \\ Campus C Mulyorejo, Surabaya, East Java 60115, Indonesia
}

\begin{abstract}
Introduction: Contact dermatitis is inflammation caused by substance which attaches to the skin. This contact dermatitis is divided into two, which are irritant contact dermatitis and allergic contact dermatitis. The purpose of this study was to analyze the factors associated with the incidence of contact dermatitis that occurred in translucent farmers in Ambulu village, Ambulu District, Jember district. Methods: The type of this research was observational analytic research with a cross-sectional approach. The population in this study was 61 tobacco farmers of ambulu village, taken by simple random sampling technique to obtain 53 tobacco farmers. The independent variables in this study were tenure, the frequency of contact, the duration of contact and age. The dependent variable was contact dermatitis. The test used to determine whether there was a relationship was the Chi-Square test. Results: This study were the results of frequency analysis of tobacco farmer contacts having a p-value of 0.020 smaller than 0.05 it is means that there was a relationship. The duration of contact p-value of 0.000 smaller than 0.05 so that there was a relationship between contact time and contact dermatitis. For the work period variables, there was not a relationship with contact dermatitis with p-value 0.210 greater than 0.05 , while for the results of the age analysis obtained a p-value of 0.455 so that there was no relationship between over and contact dermatitis. Conclusion: There is a relationship between the frequency of contact and the duration of contact with contact dermatitis whereas for the working period and age there is no relationship with contact dermatitis.
\end{abstract}

Keywords: contact dermatitis, tobacco farmers

\section{ABSTRAK}

Pendahuluan: Dermatitis kontak adalah inflamasi atau peradangan yang disebabkan oleh bahan atau substansi yang menempel pada kulit. Dermatitis kontak ini dibagi menjadi dua, yaitu dermatitis kontak iritan dan dermatitis kontak alergi. Tujuan dari penelitian ini adalah untuk menganalisi faktor yang berhubungan dengan kejadian dermatitis kontak yang terjadi pada petani tembakau di desa Ambulu, Kecamatan Ambulu, Kabupaten Jember. Metode: Jenis penelitian ini adalah penelitian analitik observasional dengan pendekatan cross-sectional. Populasi dalam penelitian ini adalah seluruh petani tembakau yang ada di desa ambulu sebanyak 61 petani kemudian diambil sampel dengan teknik simple random sampling dan di dapat hasil sebanyak 53 petani tembakau. Variabel independent dalam penelitian ini adalah Masa kerja, frekuensi kontak, Lama kontak dan usia.Variabel dependent adalah dermatitis kontak. Uji yang digunakan untuk mengetahui ada tidaknya hubungan adalah uji Chi Square. Hasil: Hasil analisis frekuensi kontak petani tembakau memiliki p value 0,020 lebih kecil dari 0,05 artinya terdapat hubungan, lama kontak p value 0,000 lebih kecil dari 0,05 yang artinya terdapat hubungan antara lama kontak dengan dermatitis kontak. Untuk variable masa kerja tidak memiliki hubungan dengan dermatitis kontak degan p value 0,210 lebih besar dari 0,05 sedangkan untuk hasil analisis usia di peroleh $p$ value sebesar 0,455 yang artinya tidak ada hubungan antara usai dan dermatitis kontak. Simpulan: Terdapat hubungan antara frekuensi kontak dan lama kontak dengan dermatitis kontak sedangkan untuk masa kerja dan usia tidak terdapat hubungan dengan dermatitis kontak

Kata kunci: dermatitis kontak, petani tembakau

Author for Correspondence:

Ike Puspitasari Singgih Putri

Email: ikesinggih01@gmail.com

Telephone: +6285257783994

(C)2020 IJOSH. Open access under CC BY NC-SA license doi: 10.20473/ijosh.v9i1.2020.95-103. Received January 11, 2019, received in revised form February 14, 2019, Accepted April 13, 2020, Published: April 2020 


\section{INTRODUCTION}

The agricultural sector is one sector that absorbs employment,in 2015 the agricultural sector employed 38.97 million people (Ahsan, Wiyono and Aninditya, 2012). The data obtained from the Central Statistics Agency in 2017 stated that there was 36.68 million people or around $31.86 \%$ of the total population of Indonesia working in the agricultural sector. One of the industries in the agricultural sector is the cigarette industry is reflected in the high tobacco consumption rate. Data obtained from Ahsan, Wiyono and Aninditya (2012) showed a high number for cigarette consumption in Indonesian society, there was 61 million Indonesian people are smokers. Based on data obtained from Ahsan's research in 2016, the figure of 30 billion cigarettes in 1970 increased 360 billion in 2014.

Data obtained from the Ministry of Health in 2017 stated that the number of smokers in Indonesia is $36.3 \%$ of the total population, while $67.8 \%$ of men in Indonesia are smokers. According to Ahsan, Wiyono and Aninditya (2012), tobacco consumption in Indonesia experienced a fairly rapid development from 1970, in which tobacco consumption in Indonesia ranged from the figure of 30 billion cigarettes per year to 360 billion cigarettes per year in 2014. From the description of cigarette consumption, tobacco has a sufficient big role. The role of the tobacco industry can be seen using several indicators such as GDP or gross domestic product, sources of employment and community income. In 2005 , tobacco contributed $1.66 \%$ to the amount of GDP or domestic products national gross. The cigarette industry has contributed $96 \%$ to national excise revenues (Ahsan, Wiyono and Aninditya, 2012).

One important component in the industry is tobacco farmers. In 2008, the tobacco industry employed quite a lot of labor which is as many as 3.8 million people or $93.77 \%$ of workers in the tobacco industry worked in farming, $26.69 \%$ worked as farmers, $44.72 \%$ as farm laborers and $22.36 \%$ worked at the post-harvest stage. Meanwhile for 2015, there was a significant increase of 4.15 million Indonesian workers working in the tobacco industry, where $93.77 \%$ of the workforce was absorbed in farming sector including post-harvest processing and at other stages (Ahsan, Wiyono and Aninditya, 2012).

Jember is one of the largest tobacco producer districts in East Java. Data from the Department of Agriculture of Jember Regency in 2015 found that from all sub-districts in Jember district, as many as 31 districts were all the centers of tobacco production. In each sub-district consisting of several villages, there are farmers who are specialized in planting tobacco. One sub-district that has a large area of planting land is Ambulu District. Ambulu sub-district consists of 7 villages, where all of the villages are the centers of tobacco farmers. There are several types of tobacco planted in Ambulu subdistrict. Not all villages in Ambulu sub-district plant all types of tobacco. One village that planted a large amount of tobacco and had a large amount of land was ambulu village with 61 tobacco farmers and 3 types of tobacco (Ahsan, Wiyono and Aninditya, 2012).

The activity of tobacco farmers in planting tobacco consists of several processes, those are the initial stage is the pre-planting process, the next process is the process of planting, and then the maintenance process. After the maintenance process, tobacco can be harvested. After the harvesting process is finished, the tobacco enters the postharvest process.

The pre-planting process is the initial process in the form of soil spray before the planting process. In the process of this development, tobacco farmers are at risk of being exposed to agricultural tools, even if farmers do not pay attention to their personal hygiene like a washed hand before dan after work and change work clothes everyday. After the soil is blown out, the next process is the process of planting tobacco (Ahsan, Wiyono and Aninditya, 2012).

The next process is planting in which the tobacco seeds will be added to the soil, and farmers are at risk of being exposed to microorganisms. The next process is the maintenance process in which several things must be done including the provision of fertilizers and irrigation. At this maintenance process, medicine must be given to keep tobacco leaves from being eaten by caterpillars. In this process, there is also the risk of tobacco farmers being exposed to chemicals in the form of fertilizers and if the farmers do not pay attention to their personal hygiene and do not use shoes and gloves to take fertilizers, the chemicals can directly hit their skin and cause irritation. In addition, there is still lack of clean water for washing hands which commonly is far from the farmers. If they wash their hands with less clean water, they will also pose a risk of health problems, especially skin health (Ahsan, Wiyono and Aninditya, 2012). 
Then, the harvest process will be carried out. In this process, tobacco leaves will be taken using special sharp tools. After the harvesting process is a post-harvest process. At this stage, tobacco leaves will be dried. This stage of grinding depends on the type of tobacco. There are tobacco leaves that are dried in the oven, dried in the sun using sunlight and also smoked. One of the most frequent drying processes is by using the grinding technique. In the technique of snuffing tobacco leaves, they will be strung together with a rope to be hung and then smoked. The process of arranging tobacco leaves for hanging is called nyujen in the nyujen process. In this case, there is a risk of injury that is can caused contact dermatitis if the tobacco farmers are wrong in carrying out the process, because the tool used for nyujen has a sharp edge. After the grinding process is the sorting process. In this sorting process, tobacco leaves will be sorted out according to the quality of tobacco (Sudibyo et al., 2015).

Based on the description above, there are most risks faced by tobacco farmers. One of the risks directly faced is health risks, especially skin health. Contact dermatitis is one of the health problems that occur in the skin it is potentially experienced by tobacco farmers (Sudibyo et al., 2015)

The skin is a part of the body that is used to protect the body from environmental influences (Sudibyo et al., 2015). The skin consists of 3 layers, the first is the epidermis. Epidermis is the outermost layer of the skin, the next layer is the dermis layer, dermis layer just below the epidermal layer and the last layer is the subcutaneous layer. The skin is the most extensive and outermost organ system as the body's first protection. The skin is also a general description of the patient's condition. Many systemic disorders in the body are manifested dermatologically (Smeltzer and Bare, 2012). One common skin disease is contact dermatitis (Keefner and Curry, 2004).

Contact dermatitis is a non-inflammatory disease that occurs in the skin with acute, sub-acute and chronic inflammatory properties (Djuanda, 2011). Contact dermatitis is acute or chronic inflammation that occurs on the skin caused by something touched by the skin or attached to the skin. There are two types of contact dermatitis; irritant contact dermatitis and allergic contact dermatitis (Keefner and Curry, 2004). Contact dermatitis is an inflammatory reaction manifested by direct damage to the skin which is exposed to risk factors for contact dermatitis (Jeyaratnam and Koh, 2012). The main symptoms and complaints mostly felt are feeling hot, painful or itchy (Siregar, 2009).

Irritant contact dermatitis and allergic contact dermatitis are influenced by several factors such as irritants because of pesticides and fertilizers used in the planting process, contact frequency including the number or frequency of farmers exposed to irritant materials or agricultural tools that can cause skin irritation, long contact period when farmers are exposed to the irritant materials or tools that can cause trauma to the skin, the grafting that causes the skin to become more permissible, as well as injury due to friction, environmental humidity and temperature (Cahyawati and Budiono, 2011).

The results of research conducted in California in 2008 showed that $95 \%$ of occupational skin diseases were contact dermatitis and contributed health claims $50 \%$ in the same year (Isselbacher et al., 2012). Based on Erliana (2008), 80\% of all contact dermatitis patients in Indonesia are irritant contact dermatitis and the remaining $20 \%$ are allergic contact dermatitis. Based on data obtained from the Jember District Health Office in (Sudibyo et al., 2015), contact dermatitis is included in the 10 biggest health problems.

Based on the results of observations and interviews, it was found that there were some farmers who had more than 8 hours of contact time/ day and the frequency of contact for more than 5 times a day in addition to the other factors such as tobacco farmers who do not use APD well during the work before the harvest, harvest, and post-harvest. In addition, there are some farmers who complain for being itching and experience redness in their hands and do not used to wash their hands after working. They said that they did not go to a health center or see a doctor, they just let the complaint go away on their own or by buying medicine in a shop. For this reason, this study aims to analyze the factors associated with the incidence of contact dermatitis in tobacco farmers in Ambulu village of Ambulu sub-district, Jember district. This Factors are devide into individual factor and enviromental factor. Individual factor in this research is contact frekuency and long contact. Enviromental factor is work period and age.

\section{METHODS}

This tudy used an observational analytic study design with a cross sectional approach. The independent variables in this study were the 
frequency of contact, duration of contact, work periode and age. The dependent variable of this study is contact dermatitis. Data for each variables were obtained using a questionnaire. For the determination of the diagnosis of contact dermatitis, doctor examination was performance in addition to questionnaire distributed by the researcher as additional data. This research was conducted on August 6 until August 282018 in Ambulu villange, Ambulu Sub-District, Jember Regency. The population in this study were 61 farmers in Ambulu village. The sample in this study was 53 tobacco farmers. The sampling technique was Simple Random sampling, by taken the sample randomly (Notoatmodjo, 2005).

$$
\begin{aligned}
& n=\frac{z^{2}{ }_{1} \alpha_{2} p(1-p) N}{d^{2}(N-1)+z^{2} \alpha_{2} p(1-p)} \\
& n=53
\end{aligned}
$$

$\mathrm{n}$ : minimum number of samples needed

z: statistic $Z(Z=1.96$ for alpha $5 \%)$

p: approximate proportion $(0.5)$

$\mathrm{d}$ : limit from eror

$\mathrm{N}$ : population size

This test used to analyze the relationship between the independent variables (length of service, the frequency of contact, duration of contact and age) and the dependent variable incidence of contact dermatitis in tobacco farmers in the Ambulu village. The test use computer applications with chi-square statistical tests. First, univariate analysis was conducted to see the frequency distribution of independent variables in the form of contact frequency, length of contact, length of service and age. In addition to seeing the dependent variable (contact dermatitis) the bivariate analysis was performed using a computer application for chisquare test. This test was conducted to see whether there is a relationship between the independent variables, the frequency of contact, the duration of contact, the working period and the end of the dependent contact dermatitis in tobacco farmers in Ambulu village, Ambulu sub-district, Jember District.

\section{RESULT}

\section{Characteristics of Tobacco Farmers in Ambulu Village, Ambulu Sub-district}

The characteristics of tobacco farmers in this study include age and gender. Data on respondents' characteristics were obtained through questionnaires distributed to farmers. In the age category, tobacco farmers are divided into two groups, those are groups $<30$ years and $>30$ years old. A total of 8 tobacco farmers or $15 \%$ are $<30$ years old and the remaining 45 tobacco farmers or $85 \%$ are $>30$ years old. Average age of the tobacco farmers is 40 years old. Many farmers who are on average age of 40 years old are due to the fact that many young workers are working to work as tobacco farmers due to several factors. The first factor is the price of tobacco farmers That is erratic and tend to fall in addition to an erratic season and tobacco care that is quite complicated makes many people choose not to grow tobacco.

For the frequency of tobacco farmers in Ambulu village based on gender, the number of male tobacco farmers is 14 tobacco farmers or $26.4 \%$, while the other 39 tobacco farmers or the remaining $73.6 \%$ are women. Many tobacco farmers are female because there are many male workers who prefer to work in factories rather than working as tobacco farmers. This is because working in a factory is considered to be more promising and has a smaller risk. If they plant tobacco, one of the obstacles is the main capital they must have, which is capital in the form of land. This land can be owned by buying land or by renting. In addition, tobacco seedlings and other treatments will also cost quite a lot. If a failure occurs, it will be very detrimental, this is the consideration to become a tobacco farmer.

\section{Dermatitis Contact with Tobacco Farmers}

The incidence of contact dermatitis in farmers in the Ambulu village of ambulu Sub-district, Jember District is $40 \%$ or a number of 21 tobacco farmers

Table 1. Frequency Distribution of Tobacco Farmers Based on Age in Ambulu Village 2018

\begin{tabular}{ccc}
\hline Age (Years) & Frequency (n) & Percentage (\%) \\
\hline$<30$ & 8 & $15 \%$ \\
$>30$ & 45 & $85 \%$ \\
\hline Total & 53 & $100 \%$ \\
\hline
\end{tabular}

Table 2. Frequency Distribution of Tobacco Farmers Based on Gender in Ambulu Village 2018

\begin{tabular}{ccc}
\hline Gender & Frequency (n) & Percentage (\%) \\
\hline Man & 14 & $26.4 \%$ \\
Women & 39 & $73.6 \%$ \\
\hline Total & 53 & $100 \%$ \\
\hline
\end{tabular}


experience contact dermatitis, and the remaining $60 \%$ or 32 tobacco farmers do not experience contact dermatitis. For the determination of the diagnosis of contact dermatitis used doctor examination was performance in addition to questionnaire distributed by the researcher as additional data. This contact dermatitis can occur because each process in tobacco planting is at risk for contact dermatitis. In the stage of planting preparation, there are many agricultural tools that have the potential to cause injury if it is used wrongly in the work process.

Furthermore, in the planting process, fertilizer will be carried out also at risk of being exposed to irritant chemicals in the form of inorganic fertilizers. The next process is the maintenance process, which is irrigation in the afternoon and evening and spraying tobacco leaves. At this stage, tobacco farmers have the potential to be exposed to dirty water and contain many microorganisms such as viruses and bacteria. Besides, it is also at risk of being irritant in the form of spray used for spraying leaf. After the next maintenance process is the process of harvesting. In this process, tobacco leaves are cut using a tool such as a small knife which also has risks of removing skin and creating opportunities for contact dermatitis. After the harvest process is a post-harvest process, which is grinding, one of the stages in the grinding process is sticking or roasting tobacco in a rope. In the nyujen process, a tool with sharp edges is used, thus it has the potential to cause injuries that can cause contact dermatitis. From the description, it can be seen that the risk of tobacco farmers in contact dermatitis is quite large, especially if the farmers do not use personal protective equipment and do not pay attention to personal hygiene.

From the data obtained, there are some farmers who do not use PPE at work and do not pay attention to personal hygiene such as not washing hands before and after work and also not changing work clothes every day, especially clothes used for farming. The contact dermatitis that is present in tobacco farmers is mostly in the hands and feet since they are which mostly exposed in the stage of planting tobacco. The explanation above is illustrated in the Table 3.

\section{The Frequency of Contact with Tobacco Farmers}

In the frequency of contact variable, there are two categories, those are farmers with contact frequency which is $0-5$ times/day and farmers with
Table 3. Frequency Distribution of Contact Dermatitis in Tobacco Farmers in Ambulu Village 2018

\begin{tabular}{ccc}
\hline Dermatitis & Frequency (n) & Percentage (\%) \\
\hline Positive & 21 & $40 \%$ \\
Negative & 32 & $60 \%$ \\
\hline Total & 53 & $100 \%$ \\
\hline
\end{tabular}

Table 4. Frequency Distribution of Tobacco Farmers Based on Frequency of Contact in Ambulu 2018

\begin{tabular}{ccc}
\hline Frequency of Contact & Frequency (n) & Percentage (\%) \\
$0-5 \mathrm{x} /$ days & 49 & $92.5 \%$ \\
$>5 \mathrm{x} /$ days & 4 & $7.5 \%$ \\
\hline Total & 53 & $100 \%$ \\
\hline
\end{tabular}

contact frequency $>5$ times/day. In Table 4, it can be seen that respondents have contact the frequency of $0-5$ times/day for 49 tobacco farmers or $92.5 \%$, while those who have a contact frequency of $>5$ times/day as many as 4 tobacco farmers or $7.5 \%$. There are farmers who have a frequency of contact $>5$ times/day because there are farmers who are involved in several stages of tobacco planting at once. The intended stage is where the farmers come into contact with the risk factors for contact dermatitis starting from the planting stage until the post-harvest stage. For example, at the stage of preparation for planting, farmers are in contact with risky agricultural tools, thus it will be included in the calculation. If the farmers come back in contact with materials or tools that can cause contact dermatitis as in the next process, which is the maintenance process that allows farmers to contact the drugs used to spray tobacco leaves so as not to be eaten by caterpillars and irrigation carried out in the morning and evening, the water used for irrigation is not necessarily clean and may contain microorganisms that can cause contact dermatitis.

\section{Duration of Contact with Tobacco Farmers}

The length of contact variable is divided into two variables, which are farmers with contact duration of $<8$ hours and farmers who have a contact duration of $>8$ hours. Farmers who have a contact duration of $<8$ hours are $83 \%$ or as many as 44 tobacco farmers, while those with a length of contact $>8$ hours are $17 \%$ or as many as 9 farmers. Farmers who have a length of contact $>8$ hours 
are usually those who are in the stage of planting tobacco, because at this stage, tobacco requires some treatment that is quite time consuming for the farmers. It includes irrigation in the morning and evening depends on the needs of the tobacco plant itself, while at this stage tobacco must also be kept on top of the leaves so that they are not eaten by caterpillars since the quality of tobacco will affect the selling price. In addition to the process of the post-harvest process, the drying process is usually done by many farmers who work more than 8 hours per day so that tobacco can be drained immediately to be included in the sorting process according to the quality of the tobacco leaves.

\section{Working Period for Tobacco Farmers}

Working period data on tobacco farmers is obtained in the questions on the questionnaire sheet. The tenure of tobacco farmers is calculated starting from the beginning they worked as tobacco farmers until the study was conducted on August 2018. Farmers who had a working period of $<6$ years

Table 5. Frequency Distribution of Tobacco Farmers Based on Duration of Contact in Ambulu Village 2018

\begin{tabular}{ccc}
\hline Long Contact & Frequency (n) & Percentage (\%) \\
\hline$<8$ hours & 44 & $83 \%$ \\
$>8$ hours & 9 & $17 \%$ \\
\hline Total & 53 & $100 \%$ \\
\hline
\end{tabular}

Table 6. Frequency Distribution of Tobacco Farmers Based on Distribution of Working Period in Ambulu 2018

\begin{tabular}{ccc}
\hline Work Period & Frequency $(\mathbf{n})$ & Percentage $\mathbf{( \% )}$ \\
\hline$<6$ years & 39 & $73.6 \%$ \\
$>6$ years & 14 & $26.4 \%$ \\
\hline Total & 53 & $100 \%$ \\
\hline
\end{tabular}

Tabel 7. Correlation between Frequency of Contact and Dermatitis in Ambulu Village 2018

\begin{tabular}{|c|c|c|c|c|c|c|c|}
\hline \multirow{3}{*}{$\begin{array}{l}\text { Frequency } \\
\text { of Contact }\end{array}$} & \multicolumn{4}{|c|}{ Frequency } & \multirow{2}{*}{\multicolumn{2}{|c|}{ Total }} & \multirow{3}{*}{ p-value } \\
\hline & \multicolumn{2}{|c|}{ Dermatitis } & \multicolumn{2}{|c|}{$\begin{array}{l}\mathbf{N} \quad 0 \quad t \\
\text { Dermatitis }\end{array}$} & & & \\
\hline & $\mathbf{n}$ & $\%$ & $\mathbf{n}$ & $\%$ & $\mathbf{N}$ & $\%$ & \\
\hline $0-5$ & 17 & 34.4 & 32 & 65.3 & 49 & 100 & \\
\hline$>5$ & 4 & 100 & 0 & 0 & 4 & 100 & 0.020 \\
\hline Total & 21 & 39.6 & 32 & 60.4 & 53 & 100 & \\
\hline
\end{tabular}

were $73.6 \%$ or as many as 39 tobacco farmers. Meanwhile, farmers who have a working period of $>$ 6 years is $26.4 \%$ or as many as 14 tobacco farmers.

\section{Correlation between Frequency of Contact and Dermatitis}

The frequency of contact with tobacco farmers was tested statistically using computer applications with the chi-square test. From the results of statistical tests using chi-square in getting results, there is a relationship between independent variables with a dependent variable contact dermatitis that occurs in tobacco farmers.

The $\mathrm{P}$-value obtained is 0.020 where the $\mathrm{p}$ value is smaller than 0.05 . For the strong relationship between contact frequency and contact dermatitis, the results of contingency coefficients were obtained with a value of 0.333 , which means that the strong value of the relationship is in the moderate category between the frequency of contact with contact dermatitis in tobacco farmers in ambulu village of Ambulu, Jember district.

\section{Correlation Duration of Contact with Dermatitis Contact in Tobacco Farmers}

From the results of statistical tests, it can be seen that contact length and contact dermatitis obtain a probability value or $p$-value of 0.000 at $\alpha$ of $5 \%$ or 0.05 it is means that there is a relationship between the duration of contact and contact dermatitis. This is because the P-value is smaller than $\alpha$ of 0.05 , with a correlation value of 0.487 so that it falls into the category of strong moderate relationships. So the variable length of contact has a relationship with contact dermatitis with a strong moderate relationship with tobacco farmers in Ambulu Village, Ambulu Sub-district, Jember.

\section{Correlation between Working Period and Dermatitis Contact with Tobacco Farmers}

Based on Table 9, the working period is divided into 2 categories, which are tobacco farmers who have a working period of $<6$ years and $>6$ years. The work period in this study was calculated starting from the beginning the respondents worked as tobacco farmers until the time this research was conducted. From the results of statistical tests, it can be seen that the working period and contact dermatitis obtain a probability value or $p$-value of 0.214 at $\alpha$ of $5 \%$ or 0.05 it is means that there is no relationship between period of work with contact 
Table 8. Correlation Between Duration of Contact and Contact Dermatitis in Ambulu Village 2018

\begin{tabular}{|c|c|c|c|c|c|c|c|}
\hline \multirow{3}{*}{$\begin{array}{l}\text { Duration } \\
\text { of Contact }\end{array}$} & \multicolumn{4}{|c|}{ Frequency } & \multirow{2}{*}{\multicolumn{2}{|c|}{ Total }} & \multirow{3}{*}{ p-value } \\
\hline & \multicolumn{2}{|c|}{ Dermatitis } & \multicolumn{2}{|c|}{$\begin{array}{l}\mathbf{N} \quad 0 \quad t \\
\text { Dermatitis }\end{array}$} & & & \\
\hline & $n$ & $\%$ & $n$ & $\%$ & $\mathbf{N}$ & $\%$ & \\
\hline$<8$ & 12 & 27.3 & 32 & 72.7 & 36 & 100 & \multirow{3}{*}{0.487} \\
\hline$>8$ & 9 & 100 & 0 & 0 & 9 & 100 & \\
\hline Total & 21 & 39.6 & 32 & 60.4 & 53 & 100 & \\
\hline
\end{tabular}

Table 9. Correlation Between Work Period and Contact Dermatitis in Ambulu Village 2018

\begin{tabular}{|c|c|c|c|c|c|c|c|}
\hline \multirow{3}{*}{$\begin{array}{c}\text { W o r k } \\
\text { Period }\end{array}$} & \multicolumn{4}{|c|}{ Frequency } & \multirow{2}{*}{\multicolumn{2}{|c|}{ Total }} & \multirow{3}{*}{ p-value } \\
\hline & \multicolumn{2}{|c|}{ Dermatitis } & \multicolumn{2}{|c|}{ 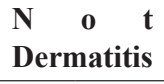 } & & & \\
\hline & $\mathbf{n}$ & $\%$ & $\mathbf{n}$ & $\%$ & $\mathbf{N}$ & $\%$ & \\
\hline$<6$ & 13 & 33.3 & 26 & 66.7 & 39 & 100 & \\
\hline$>6$ & 8 & 57.1 & 6 & 42.9 & 14 & 100 & 0.214 \\
\hline Total & 21 & 39.6 & 32 & 60.4 & 53 & 100 & \\
\hline
\end{tabular}

dermatitis in tobacco farmers in Ambulu village, Ambulu sub-district, Jember district.

\section{Correlation of Age with Dermatitis in Contact with Tobacco Farmers}

The age variable in this study was obtained through the questions in the questionnaire. In this variable, the results of the average age of tobacco farmers in the ambulu village are 40 years. In this study obtained $p$ value of 0.455 . P-value is greater than alpha 0.05 so that the results obtained there is no relationship between the variables after contact dermatitis in tobacco farmers in the village of Ambulu, Sub-District of Ambulu, Jember district.

\section{DISCUSSION}

\section{Correlation between Duration of Contact and Contact Dermatitis}

The length of contact time or the period of a person works for one day is generally the Duration of contact of workers of 8 hours a day (Suma'mur, 2009). Duration of contact affects the incidence of occupational contact dermatitis. The longer contact with irritants and allergens, the inflammation or skin
Table 10. Correlation Between Age and Contact Dermatitis in Ambulu Village 2018

\begin{tabular}{|c|c|c|c|c|c|c|c|}
\hline \multirow{4}{*}{ Age } & \multicolumn{4}{|c|}{ Frequency } & \multirow{3}{*}{\multicolumn{2}{|c|}{ Total }} & \multirow{4}{*}{ p-value } \\
\hline & \multirow{2}{*}{\multicolumn{2}{|c|}{ Dermatitis }} & \multirow{2}{*}{\multicolumn{2}{|c|}{$\begin{array}{l}N \quad 0 \quad t \\
\text { Dermatitis }\end{array}$}} & & & \\
\hline & & & & & & & \\
\hline & $\mathrm{n}$ & $\%$ & $n$ & $\%$ & $\mathbf{N}$ & $\%$ & \\
\hline$<30$ & 2 & 25 & 6 & 75 & 8 & 100 & \\
\hline$>30$ & 19 & 42.2 & 26 & 57.8 & 45 & 100 & 0.455 \\
\hline Total & 21 & 39.6 & 32 & 60.4 & 53 & 100 & \\
\hline
\end{tabular}

irritation can occur, causing deeper damage to the outer layer of skin cells (Lestari and Utomo, 2007).

The duration of contact in the study is divided into 2 categories, they are tobacco farmers who had a contact duration of $<8$ hours a day and tobacco farmers who had a length of contact $>8$ hours a day. From the results obtained, contact duration has a relationship with the incidence of contact dermatitis in farmers of the ambulu village. The value of the correlation obtained is 0.487 it is means that it has a strong relationship in the medium category.

Based on the results of the observations carried out during the study, period of contact is related because some farmers had positive contact dermatitis since they worked $>8$ hours a day, this was because the farmer worked on the process of planting and maintaining tobacco so that it takes quite a long time in maintaining tobacco and make tobacco farmers have a longer contact with factors that can cause contact dermatitis. At this stage, farmers must irrigate or irrigate tobacco plants in the afternoon and morning depends on the needs of the plants. In addition, farmers also have to keep tobacco leaves from being eaten by caterpillars, because the selling price of tobacco depends on the quality of tobacco leaves.

The results of this study are in line with the theory put forward by Suma'mur (2009) that if a person works for more than 8 hours in a day, it will cause a decrease in the level of effectiveness, efficiency, and optimal work productivity and if it is done in a prolonged time, it will cause fatigue and disruption health. In addition, the results of this study are also in line with the results of a study conducted by Lestari and Utomo (2007) who stated that contact duration affects the incidence of contact dermatitis, the longer the contact with factors that can cause contact dermatitis, the greater the likelihood of contact dermatitis. This research is also in line with the results of research entitled 
Factors Associated With Dermatitis Contact in Nalayan in Lamanggu Village, Tomia sub-District, Wakatobi District in 2016, in this reseach mention that duration of contact has a relationship with the incidence of contact dermatitis

\section{Correlation of Frequency of Contact and Contact Dermatitis}

The frequency of contacts in this study is divided into 2 categories. The first category is farmers with contact frequency of 0-5 times a day and the second tobacco farmers with contact frequency $>5$ times a day. The frequency of contact referred to this study is the amount time of tobacco farmers are in contact with the tobacco planting process. The calculated contact is when farmers come into contact with mechanical factors such as sharp agricultural implements during the process of soil spraying, harvesting processes, as well as postharvest processes especially when nyujen or meronce tobacco leaves for further drying. Then, in addition to mechanical factors, there are also chemical factors, during the giving of fertilizers and spraying drugs to the leaves. Besides chemical factors, there are also microbiological factors in the form of viruses, bacteria and other microorganisms.

The frequency of this contact is used to see the relationship, that the more often farmers are in contact with susbatance or factors that can cause contact dermatitis, the more likely someone is to get contact dermatitis. Based on the results of the analysis carried out, it is known that the contact frequency has a p-value of 0.020 where the number is greater than the alpha of 0.05 . Because the $p$-value is greater than alpha, there is a relationship between the frequency of contact with contact dermatitis in tobacco farmers in Ambulu Village, Ambulu District, Jember District. For a strong test of the relationship in getting the results of 0.333 where the results are included in the strong medium relationship.

The results of this study are in line with the theory put forward by Djuanda (2011) who stated that the more a person works with factors that are at risk of causing eating contact dermatitis the more likely a worker is exposed to contact dermatitis. In addition to the theory put forward by the results of this study, it is also in line with the theory put forward by Cohen (2011) who stated that repeated contact frequencies can cause workers to have a greater risk of the possibility of contact dermatitis. Another result of the study that is in line is that the research conducted by Nuraga, Lestari and
Kurniawidjaja (2008) showed the proportion of workers who experienced contact dermatitis with a contact frequency of 7 times a day at $92.5 \%$, while for populations that had a contact frequency $<7$ times a day is $64.88 \%$. This shows that there is a connection between contact dermatitis and the frequency of contact of farmers. This research is also reinforced by a similar study by Putri and Martiana (2016) who stated that the longer the exposure to food, the greater the risk of experiencing occupational illness which is also due to work relationships.

\section{Correlation of Work Period and Contact Dermatitis}

The longer a person is at work, the more they will be exposed to hazards caused by his work environment (Suma'mur, 2009). In this research, the average working period of farmers is around 6 years. Respondents who experienced contact dermatitis who have a working period of $<6$ years as many as 13 respondents, while those who have a working period $>6$ years as many as 8 respondents, and the remaining 32 did not experience contact dermatitis. From the results of statistical tests, it can be seen that age and contact dermatitis obtain a probability value or $p$-value of 0.214 at $\alpha$ of $5 \%$ or 0.05 , which means that there is no relationship between years of service with contact dermatitis. This might happen because there are a number of other factors that are more influential. It can be seen that the farmers who are most affected by contact dermatitis are in the category of $<6$ years working period. Other factors meant are the frequency of contact, personal hygiene, and length of work. From the questionnaire results obtained data, many farmers have a working period of $>6$ years but have contact length $<8$ hours a day and the frequency of contact of 0-5 times a day, plus good personal hygiene by washing hands and feet before and after work and change work clothes every day. The results of this study are in line with the results of the study with the title of factor factors associated with laundry contact dermatitis in 2014.

\section{Correlation of Age with Contact Dermatitis}

The results of this study found that there was no relationship between age and the incidence of dermatitis in contact with tobacco farmers in Ambulu Village. The absence of a relationship between age and the incidence of contact dermatitis is due to 
the age of tobacco farmers, most of whom have age $<30$ years, so the data is not proportional to the strong relationship because there is no difference. The results of this study are in line with the research conducted by Erliana (2008) in this study stating that contact dermatitis affects many age groups, meaning age is not a major factor. In this study, 50\% of workers in the 30-35 year age group experienced contact dermatitis, while at the age of $36-40$ years, $33.3 \%$ for ages $24-29$ years as much as $16.7 \%$ which means contact dermatitis can occur at all ages.

\section{CONCLUSION}

As much as $40 \%$ of tobacco farmers in Ambulu Village, Ambulu District, Jember Regency, have contact dermatitis. The average frequency of contact with tobacco plants is $0-5$ times a day, while for the the length of contact variable, most farmers have a contact duration of $<8$ hours a day. As for the working period, the average owned by farmers is $<6$ years. For age variables, most tobacco farmers are in the first category, $<30$ years. There is a relationship between the frequency of contact and the duration of contact with the incidence of contact dermatitis in tobacco farmers in Ambulu Village. For the working period and age, there is no relationship with the incidence of contact dermatitis in tobacco farmers in Ambulu Village, Ambulu Sub-district, Jember District.

\section{ACKNOWLEDGEMENT}

The researcher thanks the Anita Dewi P.S., S.KM., M.SC for the guidance and advice given so that the writer can finish writing this journal.

\section{REFERENCES}

Ahsan, A., Wiyono, N. H. and Aninditya, F. (2012) Beban Konsumsi Rokok, Kebijakan Cukai dan Pengentasan Kemiskinan. Scientific Articles. Depok: Demographic Institute, Faculty of Economic, Universitas Indonesia.

Cahyawati, I. N. and Budiono, I. (2011) 'Faktor yang Berhubungan dengan Kejadian Dermatitis pada Nelayan', KEMAS: Jurnal Kesehatan Masyarakat, 6(2), pp. 134-141.

Cohen, D. E. (2011) 'Occupational Dermatosis', in DiBerardinis, L. J. (ed.) Handbook of Occupational
Safety and Healthy. 2nd edn. Canada: Jhon Wiley and Sons Inc.

Djuanda, A. (2011) Ilmu Penyakit Kulit dan Kelamin. 5th edn. Jakarta: Faculty of Medicine Universitas Indonesia.

Erliana (2008) Hubungan antara Karakteristik Individu dan Penggunaan Alat Pelindung Diri dengan Kejadian Dermatitis Kontak pada Pekerja Paving Block CV.F Lhoksemawe pada Tahun 2008. Medan: Magister Public Health Science, Universitas Sumatera Utara.

Isselbacher, K. J. et al. (2012) Harrison: Prinsipprinsip Ilmu Penyakit Dalam. 13th edn. Edited by A. H. Asdie. Jakarta: EGC.

Jeyaratnam, J. and Koh, D. (2012) Buku Ajar: Praktik Kedokteran Kerja. Edited by R. N. E. Sihombing and Suryadi. Jakarta: EGC.

Keefner, D. . and Curry, C. E. (2004) 'Contact Dermatitis', in Handbook of Nonprescription Drugs. 12th edn. Washington D.C: American Pharmacists Association.

Lestari, F. and Utomo, H. S. (2007) 'Faktor-faktor yang Berhubungan dengan Dermatitis Kontak pada Pkerja di PT Pantja Press Industri', Makara Kesehatan, 11(2), pp. 61-68.

Notoatmodjo, S. (2005) Metode Penelitian Kesehatan. Jakarta: Rineka Cipta.

Nuraga, W., Lestari, F. and Kurniawidjaja, L. M. (2008) 'Dermatitis Kontak pada Pekerja yang Terpajan dengan Bahan Kimia di Perusahaan Industri Otomotif Kawasan Industri Cibitung Jawa Barat', Makara Kesehatan, 12(2), pp. 63-69.

Putri, W. W. and Martiana, T. (2016) 'Hubungan Usia dan Masa Kerja dengan Nilai Ambang Dengar Pekerja yang Terpapar Bising di PT X Sidoarjo', The Indonesian Journal of Occupational Safety and Health, 5(2), pp. 173-182.

Siregar, R. S. (2009) Dermatosis Akibat Kerja. Palembang: Ilmu Penyakit Kulit dan Kelamin Fakultas Kedokteran Universitas Sriwijaya.

Smeltzer, S. and Bare, B. G. (2012) Buku Ajar Keperawatan Medikal Bedah. 2nd edn. Jakarta: EGC.

Sudibyo, M. et al. (2015) Petani Tembakau di Indonesia : Sebuah Paradoks Kehidupan. Edited by A. Mulyana. Jakarta: Lembaga Pengembangan Sosial Indonesia.

Suma'mur (2009) Higiene Perusahaan dan Kesehatan Kerja. Jakarta: Gunung Agung. 